\title{
LIMITES NORMATIVOS PARA A DESCONSIDERAÇÃO DA PERSONALIDADE JURÍDICA NO CUMPRIMENTO DA SENTENÇA
}

\section{REGULATORY LIMITS OF THE DISREGARD DOCTRINE IN THE JUDGEMENT EXECUTION}

\section{Luiz Gustavo Lovato ${ }^{1}$}

Resumo: A teoria da desconsideração da personalidade jurídica constitui uma eficiente ferramenta para evitar o enriquecimento ilícito decorrente do uso irregular da personalidade jurídica. Seja a desconsideração direta da personalidade jurídica, a inversa ou a entre grupos econômicos, o instituto tem por objetivo a inoponibilidade dos limites de responsabilidade previstos no contrato social perante o juízo. $\mathrm{O}$ instituto é processado como forma de intervenção de terceiro, e todos os envolvidos devem ser citados no processo. Quando o incidente é instaurado na fase de cumprimento da sentença, porém, surge a questão da legitimidade. Quem não participou da fase de conhecimento do processo não possui legitimidade para participar da fase executiva. A decisão que julga procedente o pedido de desconsideração da personalidade jurídica deve, então, ser modulada para definir quais sujeitos terão legitimidade para participar do processo em sua fase executória.

Palavras-chaves: Desconsideração da Personalidade Jurídica. Processo Civil. Cumprimento da Sentença.

Abstract: The disregard doctrine theory constitutes an efficient tool to prevent illicit enrichment arising from the irregular use of legal personality. Being the disregard direct, inverse or among economic groups, it aims to prevent the opposition of the responsibility limits written on the social contract. The institute is processed as a third part intervention, and all those involved must be brought to the process. When the situation occurs during the judgement execution, there is the question of legitimacy. Those who did

1 Advogado e professor dos cursos de graduação e pós graduação da Faculdade CESUSC e da UNISUL; mestre em jurisdição e processo pela Pontifícia Universidade Católica do Rio Grande do Sul, professor convidado da Escola Superior da Magistratura do Estado de Santa Catarina e da Escola Superior da Advocacia da OAB/SC, membro permanente do IBDP - Instituto de Direito Processual Civil. 
not appear on the cognition stage can not be responsible for the judgement execution. The decision of applying the disregard doctrine must be modulated to define which subjects will have legitimacy to participate in the enforcement stage.

Keywords: Disregard Doctrine. Civil Procedure. Judgement Execution.

\section{INTRODUÇÃO}

Personalidade jurídica é instituto de direito material que visa separar a pessoa da sociedade empresarial da pessoa natural dos sócios, através de um ato formal consubstanciado no contrato societário, ou contrato social, devidamente registrado no órgão público competente. Mas deve-se ressaltar que a sociedade empresarial, a empresa, e a firma, não possuem, necessariamente, uma natureza contratual formal. Há, desde o começo do século XX, uma separação entre a atividade empresarial e a personalidade jurídica regularmente constituída, que merece nota.

Segundo Nicolai J. Foss (FOSS, 2018), a visão contratual da empresa especifica os recursos ativos, enquanto a não contratual trata de todos os elementos que compõem a atividade, como a coordenação de conhecimentos e as opções estratégicas de mercado. É questão que ultrapassa a simples formalização.

Nem toda personalidade jurídica é empresa. E nem toda empresa possui personalidade jurídica regularmente constituída. Uma personalidade jurídica pode ser uma associação, uma fundação, um condomínio ou uma sociedade simples, para dar exemplos. O Superior Tribunal de Justiça, no Informativo $\mathrm{n}^{\circ} 602$ (STJ, 2018), fixou o entendimento de que "O art. 1.023 do $\mathrm{CC} / 02$ - que trata da responsabilidade dos sócios da sociedade simples - não se aplica às associações civis." Nessa esteira, deve ser considerado que o legislador não limitou a aplicação do instituto da desconsideração da personalidade jurídica às sociedades empresariais, mas, genericamente, àquelas que 
possuem personalidade jurídica regularmente constituída. Sobre o tema, é a lição de Orlando Gomes, em acepção adotada sob a égide do Código Civil de 1916:

O fenômeno da personalização de certos grupos sociais é contingência inevitável do fato associativo. Para a realização de fins comuns, isto é, de objetivos que interessam a vários indivíduos, unem eles seus esforços e haveres, numa palavra, associam-se. [...] surge, assim, a necessidade de personalizar o grupo, para que possam proceder como uma unidade, participando do comércio jurídico com individualidade, tanto mais necessária quanto a associação, via de regra, exige a formação de patrimônio comum constituído pela afetação dos bens particulares dos seus componentes. Esta individualização necessária só se efetiva se a ordem jurídica atribui personalidade ao grupo, permitindo que atue em nome próprio, com capacidade jurídica igual à das pessoas naturais. (GOMES, 1996, p. 185-186).

O Código Civil (BRASIL, 2018), no seu art. 45, definiu duas hipóteses de tratamento das atividades empresariais, sendo que a formalização, que define o início da atividade personificada, depende "[...] da inscrição do ato constitutivo no respectivo registro, precedida, quando necessário, de autorização ou aprovação do Poder Executivo, averbando-se no registro todas as alterações por que passar o ato constitutivo." A figura da personalidade jurídica regularmente constituída traz todas as características necessárias para contrair obrigações, responsabilidades e atos de gestão e administração. Segundo o art. 46 do Código Civil (BRASIL, 2018), o contrato societário regularmente constituído deve trazer a denominação, os fins, a sede, o tempo de duração e o fundo social, quando houver; o nome e a individualização dos fundadores ou instituidores, e dos diretores; o modo por que se administra e representa, ativa e passivamente, judicial e extrajudicialmente; se o ato constitutivo é reformável no tocante à administração, e de que modo; se os membros respondem, ou não, subsidiariamente, 
pelas obrigações sociais; as condições de extinção da pessoa jurídica e o destino do seu patrimônio, nesse caso.

Se inexistente, ou, existente mas não registrado o contrato societário, a responsabilidade dos sócios será ilimitada perante terceiros, aplicando-se o Código Civil no que tange à sociedade não personificada, em seus arts. 986 e seguintes. (BRASIL, 2018). E é nesse ponto que se justifica a desconsideração da personalidade jurídica, como será visto no item adiante. Sobre os efeitos decorrentes da personalidade jurídica, é a lição de Ricardo Negrão (NEGRÃO, 2007, p. 179):

Na constituição das sociedades, o registro do contrato social ou dos estatutos faz nascer a pessoa jurídica. São efeitos da personalidade jurídica:

- a assunção da capacidade para direitos e obrigações;

- os sócios não mais se confundem com a pessoa da sociedade;

- a pessoa jurídica possui patrimônio próprio, distinto do de seus sócios;

- a sociedade pode alterar sua estrutura interna.

A desconsideração da personalidade jurídica, durante muito tempo, foi um instituto reconhecido pela lei de direito material e pelos microssistemas legislativos, mas que carecia de uma regulamentação do seu processamento. O Código de Defesa do Consumidor trouxe a previsão do instituto já em 1990, conferindo-lhe uma abrangência ilimitada, mas também sem definir o procedimento. O legislador poderia tê-lo feito, já que se trata de um microssistema legislativo.

Já em 2002, o Código Civil definiu as hipóteses de cabimento da desconsideração da personalidade jurídica mas, como norma eminentemente de direito material, não estabeleceu os meios para o seu processamento. Mais, pode-se dizer que trouxe uma norma aberta, com limites de proporções um tanto amplas, que ensejaram inúmeras interpretações diversas 
pelos tribunais, causando, como sempre ocorre nesses casos de amplitude exacerbada, a moléstia da insegurança jurídica.

\section{O INSTITUTO DA DESCONSIDERAÇÃO DA PERSONALIDADE JURÍDICA}

Atividade empresarial e empresa possuem conotações distintas, e não se confundem com o conceito de personalidade jurídica. Enquanto a atividade empresarial constitui toda a atividade realizada pelo empresário com o objetivo de lucro, a empresa, em sua visão contratual, traz muito menos. Pode-se dizer que o contrato societário é apenas um dos elementos da atividade empresarial, que regula a relação entre os sócios e a relação da empresa e dos sócios perante terceiros. Justamente por isso, o contrato societário é oponível a todas as pretensões deduzidas em decorrência da atividade empresarial.

O contrato societário é oponível entre os sócios, para as pretensões de haveres no decorrer da atividade societária e na dissolução, parcial ou total, da personalidade jurídica. É oponível perante terceiros, delimitando a responsabilidade pessoal dos sócios pelas dívidas da empresa, desde que regularmente registrado nos órgãos públicos competentes. E isso se aplica às alterações do contrato social. Contrato não registrado é inoponível perante terceiros, mas terá valor entre os seus signatários, que são os sócios.

Com base nessas premissas, desconsiderar a personalidade jurídica significa mantê-la íntegra e hígida, mas ignorar absolutamente todas as previsões do contrato societário que limitam responsabilidades ${ }^{2}$. Significa dizer que, para o juízo que a determina, a empresa equipara-se à atividade empresarial não personificada, em que os sócios respondem integralmente pe-

2 Neste sentido, o art. 790, do Código de Processo Civil, dispõe que são sujeitos à execução os bens do sócio, nos termos da lei; e do responsável, nos casos de desconsideração da personalidade jurídica. 
las dívidas da empresa, e vice-versa. Segundo o art. 990, do Código Civil, “[...] todos os sócios respondem solidária e ilimitadamente pelas obrigações sociais, excluído do benefício de ordem, previsto no art. 1.024 [do Código Civil], aquele que contratou pela sociedade." (BRASIL, 2018).

Existem duas teorias da desconsideração da personalidade jurídica: a maior e a menor ${ }^{3}$. O Código Civil, em seu art. 50 (BRASIL, 2018), prevê a maior, e trouxe como requisitos legais para a instauração do incidente da desconsideração da personalidade jurídica o abuso, configurado por:

a) a confusão patrimonial; e

b) o desvio da finalidade.

A tais requisitos legais, o STJ consolidou o entendimento, através do Informativo n. 0554 (STJ, 2018), de que se acrescentam outros, não previstos expressamente na lei:

$\mathrm{O}$ encerramento das atividades da sociedade ou sua dissolução, ainda que irregulares, não são causas, por si sós, para a desconsideração da personalidade jurídica a que se refere o art. 50 doCC. Para a aplicação da teoria maiorda desconsideração da personalidade social - adotada pelo $\mathrm{CC}$-, exige-se o dolo das pessoas naturais que estão por trás da sociedade, desvirtuando-lhe os fins institucionais e servindo-se os sócios ou administradores desta para lesar credores ou terceiros. É a intenção ilícita e fraudulenta, portanto, que autoriza, nos termos da teoria adotada pelo $\mathrm{CC}$, a aplicação do instituto em comento.

Não existe uma lógica objetiva nesse entendimento, mas apenas abstrata, que considera as consequências da aplicação do instituto da desconsideração da personalidade jurídica

3 Serão analisadas tais teorias sob a ótica do Código Civil e do Código de Defesa do Consumidor, respectivamente. $\mathrm{O}$ instituto da desconsideração da personalidade jurídica (e os seus requisitos legais) estão previstos em outras partes do ordenamento jurídico, como no Código Tributário Nacional, na Lei n. 9.605/98, na Lei n. 12.259/11 e na Lei n. 12.846/13. 
como excessivamente fortes, na livre disposição dos bens do executado. Esse entendimento, como será visto adiante, causa um embaraço na aplicação da desconsideração da personalidade jurídica, pois somente os sócios com poderes de gestão empresarial podem praticar tais atos dolosos e, por conseguinte, atacar o patrimônio daqueles sócios sem poderes de gestão se mostra ilícito, sob o ponto de vista da norma hermenêutica.

Talvez alguma lógica resida na necessidade de se comprovar o dolo da pessoa natural nas hipóteses de confusão patrimonial, apesar de o requisito legal ser claramente objetivo. Mas nenhuma lógica reside na necessidade de se comprovar o dolo no desvio da atividade-fim prevista no contrato societário. Isso porque, ao realizar atividade empresarial não especificada no contrato, a personalidade jurídica está realizando atividade empresarial não personificada, e, para tal, o Código Civil prevê que a responsabilidade dos sócios será integral e ilimitada. Atividade empresarial exercida fora das finalidades do contrato societário é atividade não personificada, por óbvio.

Com base nessa premissa, o próprio STJ consolidou o entendimento, no Informativo n. 0544 (STJ, 2018), de que o juiz, após a desconsideração da personalidade jurídica, poderá atingir os bens dos sócios ou dos administradores, tornando a decisão modulável quanto aos sujeitos. Também, no Informativo n. 0524 que assevera:

É certo que, a despeito da inexistência de qualquer restrição no art. 50 do CC/2002, a aplicação da desconsideração da personalidade jurídica apenas deve incidir sobre os bens dos administradores ou sócios que efetivamente contribuíram para a prática do abuso ou fraude na utilização da pessoa jurídica. Todavia, no caso de sociedade limitada modesta na qual as únicas sócias sejam mãe e filha, cada uma com metade das quotas sociais, a titularidade de quotas e a administração da sociedade se confundem, situação em que as deliberações sociais, na maior parte 
das vezes, ocorrem no dia a dia, sob a forma de decisões gerenciais. (STJ, 2018).

Dentre as modalidades de desconsideração da personalidade jurídica, tem-se a direta (vista acima), a inversa e a desconsideração entre grupos econômicos ou grupos societários. A desconsideração inversa da personalidade jurídica tem por objetivo atingir a personalidade jurídica pela dívida pessoal do seu sócio. Extrai-se da casuística prevista no Informativo n. 0533, do STJ:

Se o sócio controlador de sociedade empresária transferir parte de seus bens à pessoa jurídica controlada com o intuito de fraudar partilha em dissolução de união estável, a companheira prejudicada, ainda que integre a sociedade empresária na condição de sócia minoritária, terá legitimidade para requerer a desconsideração inversada personalidade jurídica de modo a resguardar sua meação. (STJ, 2018).

O Código de Defesa do Consumidor (CDC - Lei n. 8.078/90), por sua vez, estabelece os requisitos da regulação da desconsideração da personalidade jurídica no seu art. 28, adotando a chamada teoria menor, os quais são bem menos restritos. Antes de analisar esses requisitos, é importante salientar que o entendimento do STJ, anteriormente apresentado, de que se faz necessária a atuação dolosa do empresário, não pode ser aplicado ao caso da relação consumerista. Isso porque a responsabilidade do fornecedor é objetiva, o que significa que independe de dolo ou culpa. A responsabilidade culposa apenas se aplica aos fornecedores profissionais liberais, conforme dispõe o art. 14, $\S 4^{\circ}$, do CDC (BRASIL, 2018), o que pressupõe, muitas vezes, a inexistência de uma personalidade jurídica constituída e, por conseguinte, a inaplicabilidade do instituto da desconsideração.

Nas relações de consumo, a desconsideração da personalidade jurídica do fornecedor terá cabimento mediante o preen- 
chimento dos seguintes requisitos:

a) abuso de direito;

b) excesso de poder;

c) infração da lei;

d) fato ou ato ilícito;

e) violação dos estatutos ou do contrato social; ou

f) quando houver falência, estado de insolvência, encerramento ou inatividade da pessoa jurídica provocados por má administração.

Tais requisitos são alternativos, e não cumulativos. A norma é aberta, o que significa que o consumidor, protegido por sua natural situação de vulnerabilidade, não pode ser prejudicado por qualquer ato relacionado aos limites do contrato societário que impeça a responsabilização do fornecedor. Mais, o $\S 5^{\circ}$, do mesmo art. 28, torna dispensáveis todos esses requisitos, já que "[...] também poderá ser desconsiderada a pessoa jurídica sempre que sua personalidade for, de alguma forma, obstáculo ao ressarcimento de prejuízos causados aos consumidores." (BRASIL, 2018).

O Código de Defesa do Consumidor também prevê a possibilidade de desconsideração da personalidade jurídica entre sociedades de mesmo grupo econômico, sem, contudo, definir os limites dessa desconsideração. Estabelece o referido artigo que "[...] as sociedades integrantes dos grupos societários e as sociedades controladas, são subsidiariamente responsáveis pelas obrigaçõe." (BRASIL, 2018); que "[...] as sociedades consorciadas são solidariamente responsáveis pelas obrigações." (BRASIL, 2018); e que "[...] as sociedades coligadas só responderão por culpa.” (BRASIL, 2018). Falta clareza nas consequências da aplicação do instituto, se o magistrado poderá incluir os sócios e as sociedades ou somente as sociedades. Essa amplitude, a princípio, ficará a cargo do magistrado ao 
julgar o incidente, mas nada impede que todos os corresponsáveis e coobrigados venham a integrar o polo passivo da demanda em litisconsórcio.

\section{O INCIDENTE DA DESCONSIDERAÇÃO DA PERSONALIDADE JURÍDICA}

O ordenamento jurídico brasileiro sempre pecou pela ausência de normas que regulassem o processamento da desconsideração da personalidade jurídica. Durante a vigência do Código de Processo Civil de 1939, esse instituto sequer existia no Brasil. O Código Civil vigente era o de 1916, e as teorias modernas da empresa, da firma e da atividade empresarial, somente surgiram alguns anos depois. No Código de Processo Civil de 1973, também não se cogitou a regulamentação do instituto e, com o seu surgimento, as normas apenas previam os requisitos materiais para a desconsideração (os já analisados Código de Defesa do Consumidor e Código Civil de 2003). Cabia ao Poder Judiciário, em decisões muitas vezes contrastantes, definir o processamento e os efeitos da desconsideração da personalidade jurídica no processo, aplicando a equidade ao procedimento. E julgamento por equidade é um instituto excepcional, aplicável somente às hipóteses autorizadas por lei, que, no caso, era omissa.

No Código de Processo Civil de 2015, a desconsideração da personalidade jurídica foi acertadamente tratada como modalidade de intervenção de terceiro, da espécie litisconsorcial. Isso porque os citados, sejam eles sócios ou sociedades empresariais, passam a integrar o polo passivo da demanda após a estabilidade subjetiva. Mas, como salienta Cássio Scarpinella Bueno, a estranheza reside na previsão procedimental, segundo a qual o terceiro interveniente não é citado para comparecer à audiência de conciliação ou mediação, mas para apresentar defesa por petição, como se o legislador o tratasse como espécie sui generis de parte. (BUENO, 2017). 
Para regular a estabilidade subjetiva da demanda, o legislador hodierno autorizou, nos arts. 338 e 339 do CPC (BRASIL, 2018), a substituição de partes até o momento da contestação, em caso de alegação de ilegitimidade passiva pelo requerido. Em verdadeira nomeação à autoria, o requerido aponta ao autor quem venha a ser o verdadeiro legitimado, e, por aditamento da inicial, poderá ocorrer a alteração do polo passivo, substituindo-se o requerido ilegítimo pelo nominado.

Também é possível estabilizar a demanda após o esgotamento das reconvenções. A reconvenção não se limita, subjetivamente, às partes indicadas pelo autor na inicial, podendo ser oposta pelo requerido em litisconsórcio com terceiro, e em face do autor em litisconsórcio com terceiro, conforme dispõem os $\S \S 3^{\circ}$ e $4^{\circ}$ do art. 343, do CPC. (BRASIL, 2018). Nesse sentido, poderá haver reconvenção da reconvenção, já que o terceiro reconvindo está sendo demandado sem que tenha apresentado a sua pretensão ao juízo. Apresentá-la é direito seu, uma vez demandado. A reconvenção da reconvenção, a princípio, somente é vedada nas ações monitórias, por questão de organização judiciária e segurança jurídica, já que a pretensão do autor pode se converter em execução direta, conforme expressamente disposto no $\S 6^{\circ}$, do art. 702, do CPC. (BRASIL, 2018). Após o esgotamento das reconvenções, ocorre a estabilidade subjetiva da demanda, definindo-se, de modo definitivo, as partes que figurarão como sujeitos do processo.

Já no tocante ao litisconsórcio necessário, é possível que aquele que não integrou o contraditório seja incluído no processo após a prolação da sentença. Se o litisconsórcio for unitário, essa sentença será nula e a instrução deverá ser reaberta. Mas, se o litisconsórcio for não unitário, essa sentença será válida, mas ineficaz àquele que não participou da fase de conhecimento, devendo ser-lhe propiciada a oportunidade da ampla defesa, com prolação de nova sentença, exclusivamente e 
relação a tal litisconsorte tardio, conforme dispõe o art. 115, do CPC. (BRASIL, 2018). Justifica-se, já que não poderá ser executado em cumprimento de uma sentença proferida sem o respeito ao contraditório e à ampla defesa ${ }^{4}$. Sobre o tema, é a lição de Juliana Borinelli Franzoi:

O processo civil moderno é banhado pela cláusula do devido processo legal, assegurada expressamente pela Constituição da República (art. $5^{\circ}$., inciso LIV), não apenas sob um enfoque individualista da tutela de direitos subjetivos das partes, mas, sobretudo, como um conjunto de garantias objetivas do próprio processo, fator legitimante do exercício da jurisdição. (FRAZNOI, 2016, p. 224).

À exceção das hipóteses de litisconsórcio necessário e da alteração subjetiva da demanda, a estabilidade subjetiva se torna definitiva com a estabilização da decisão saneadora, prevista expressamente no $\S 1^{\circ}$, do art. 357, do CPC (BRASIL, 2018), e somente será relativizada pela intervenção de terceiro ou nas hipóteses expressamente previstas pela lei ${ }^{5}$. E isso deve ser levado em consideração tanto em relação à modalidade litisconsorcial como à modalidade simples, já que, mesmo na assistência simples, o terceiro interveniente atua como substituto processual em caso de revelia ou omissão do assistido, conforme disposto no art. 121, parágrafo único do CPC. (BRASIL, 2018).

Sob tais premissas, o legislador previu a desconsideração da personalidade jurídica como modalidade litisconsorcial de intervenção de terceiro, nos arts. 133 a 137, do Código de Processo Civil (BRASIL, 2018), denominando o instituto expressamente como incidente, em sua natureza jurídica, mas tratando-o como modalidade de ação, em seu processamento. Os requisitos le-

4 Os princípios processuais do contraditório e da ampla defesa constituem cláusula pétrea constitucional, prevista expressamente no inciso LV, do art. $5^{\circ}$, da Constituição da República Federativa do Brasil, e norma fundamental do processo civil, prevista expressamente no art. 10, do Código de Processo Civil.

5 A exemplo, o art. 110, do Código de Processo Civil, dispõe que, "ocorrendo a morte de qualquer das partes, dar-se-á a sucessão pelo seu espólio ou pelos sucessores, observado o disposto no art. $313, \S \S 1^{\circ}$ e $2^{\circ}$ ". 
gais para a instauração do incidente são aqueles presentes na lei material, sendo que o seu processamento é regulado pela norma processual. E foi nesse ponto que o legislador pecou pela falta de definição do procedimento, como dito anteriormente.

Primeiramente, a instauração do incidente de desconsideração da personalidade jurídica não pode ocorrer de ofício pelo magistrado, estando este estritamente vinculado ao pedido das partes ou do Ministério Público, pelo que estabelece expressamente o art. 133, do CPC (BRASIL, 2018). Sob a ótica do direito de ação, em que o autor apresenta pretensão e formula pedido de tutela em face do requerido, essa previsão é acertada. Mas o legislador tratou a desconsideração da personalidade jurídica como incidente, e não como ação. José Miguel Garcia Medina, sobre o tema, destaca que, "[...] a despeito de tramitar incidentalmente, a questão será resolvida como principal, de mérito, e não incidental, incidindo, no caso, o disposto no art. 503, caput, do CPC/2015, podendo ser atacada de ação rescisória [...]." (MEDINA, 2016, p. 241).

O equívoco se apresenta nas hipóteses em que o juiz possa (e deva) agir de ofício, como na fraude à execução, por exemplo. Ora, se o empresário reduz a sociedade empresarial à insolvência, transferindo para si o patrimônio empresarial, no curso de demanda que seria capaz de reduzí-la à insolvência, estarão presentes três elementos importantes:

a) a confusão patrimonial;

b) a má-fé e o intuito de fraudar; e

c) a fraude à execução.

Parece contraproducente que o magistrado, diante dessa situação hipotética, possa reconhecer a fraude à execução de ofício, mas não possa fazer a desconsideração da personalidade jurídica. Talvez o leitor conclua que, na fraude à execução, o contrato societário se torna inoponível ao juízo, sendo desneces- 
sária a citação do sócio fraudador e, por conseguinte, a instauração do incidente, pelo que se extrai dos arts. 790, II e V, do CPC. (BRASIL, 2018). E essa conclusão está correta. O problema é o efeito prático, já que todos os demais sócios se beneficiarão com esse ato, já que não terão seu patrimônio pessoal atingido, e a sua empresa permanecerá insolvente e inadimplente.

O mais interessante, talvez, seja a vinculação que o legislador deu aos institutoda desconsideração da personalidade jurídica e à fraude à execução, no art. 137, do CPC (BRASIL, 2018), fazendo com que aquela seja predicado para o reconhecimento desta. Voltando ao exemplo anterior, na fraude à execução o magistrado ataca o patrimônio transferido, independentemente de estar registrado em nome ou apenas na posse de terceiro. Não apura, por conseguinte, a participação efetiva de cada sócio no ato fraudulento. São institutos de efeitos práticos diferentes.

Seguindo a análise do Código, o legislador autorizou expressamente a instauração do incidente da desconsideração da personalidade jurídica, no art. 134, do CPC (BRASIL, 2018), "[...] em todas as fases do processo de conhecimento, no cumprimento de sentença e na execução fundada em título executivo extrajudicial." Se houver requerimento de desconsideração da personalidade jurídica formulado já na petição inicial, será dispensada a instauração do incidente, cabendo ao juiz decidir de plano e determinar a citação do sócio ou da pessoa jurídica.

No tocante ao processamento, o legislador foi econômico, nos arts. 134 e 135, do CPC (BRASIL, 2018). Limitou-se a regular que a instauração do incidente, quando formulado em momento posterior à petição inicial, suspenderá o processo e que, citado o terceiro (que pode ser o sócio ou a sociedade empresarial), este terá 15 dias para realizar a defesa do seu direito. $\mathrm{O}$ incidente é resolvido por decisão interlocutória, impugnável por agravo de instrumento, ou por decisão monocrática do relator, impugnável por agravo interno, pelo que dispõe o 
art. 136 do CPC. (BRASIL, 2018). Como visto anteriormente, José Miguel Garcia Medina discorda, com razão, dessa previsão. (MEDINA, 2016). Afinal, decisões interlocutórias não podem ser objeto de ação rescisória, mas, apenas, decisões de mérito que transitam em julgado, formal e materialmente, pelo que se extrai do art. 966 do CPC. (BRASIL, 2018).

\section{EXECUÇÃO SINCRÉTICA E POR PROCESSO AUTÔNOMO E AS DEFESAS TÍPICAS DO EXECUTADO}

A execução é uma modalidade de procedimento que se caracteriza pelo mínimo de conhecimento, pelo magistrado, acerca da pretensão do autor. Primeiramente, porque o legislador vinculou toda a prova do autor aos documentos que acompanham a inicial, no art. 798, do CPC (BRASIL, 2018), impedindo-o de requerer provas posteriores, sob pena de indeferimento da inicial. Ou o exequente comprova, na sua inicial, que é credor de obrigação certa, líquida e exigível, consubstanciada em título executivo, ou deverá adotar os procedimentos típicos das ações de conhecimento, pois tais são pressupostos de validade da ação executiva, conforme se extrai dos arts. 783 e 786 do CPC. (BRASIL, 2018).

Por não haver espaço para a cognição plena nas execuções, as matérias de defesa do executado (e a sua forma de processamento) são extremamente limitadas.Nesse sentido:

As execuções têm por principais características:

1. buscarem o cumprimento forçado de uma obrigação certa, líquida e exigível em juízo;

2. não terem por objetivo primordial uma tutela de mérito, pois isso seria absolutamente contrário à primeira característica da obrigação, que é a certeza; 
3. não serem procedimentos típicos de ações de conhecimento, pois o exequente não precisa formar o convencimento do juízo acerca da possibilidade ou não de concessão da tutela executiva no curso da ação. Havendo título executivo de obrigação certa, líquida e exigível, o magistrado deve, por força de lei, conceder a tutela executiva pretendida e providenciar o cumprimento forçado dessa obrigação constante no título executivo. Ele deverá ser convencido de que o título e a obrigação certa, líquida e exigível existem, mas isso deve ser pré-constituído, ou seja, não se produzirá essa prova no curso da execução. (LOVATO, 2016, p. 04).

Os procedimentos executivos são classificados em duas grandes vertentes: a execução do título executivo extrajudicial e o cumprimento da sentença, conforme houver, respectivamente, título executivo extrajudicial ou judicial. Dentro dessas duas grandes vertentes, ainda existem as execuções por processo autônomo e a execução sincrética, nos autos do processo que gerou o título executivo judicial. A execução por processo autônomo se aplica aos títulos extrajudiciais e aos títulos judiciais previstos nos incisos VI a IX, do art. 515 do Código de Processo Civil, conforme dispõe o $\S 1^{\circ}$, do mesmo artigo. (BRASIL, 2018).

O cumprimento da sentença por processo autônomo se justifica em razão da competência. $\mathrm{O}$ órgão que gerou o título executivo judicial não possui competência para promover a sua execução na esfera cível. Assim o são a sentença penal condenatória transitada em julgado, a sentença arbitral, a sentença estrangeira após a sua homologação pelo Superior Tribunal de Justiça e a carta rogatória após a concessão do exequatur pelo Superior Tribunal de Justiça.

Essas classificações influenciam não somente o procedimento executivo mas, principalmente, os meios de defesa do executado. $\mathrm{Na}$ execução de um título executivo extrajudicial, o executado poderá defender o seu direito por meio de embargos à execução, que serão propostos independentemente de 
qualquer garantia ou segurança do juízo, pelo que se extrai do art. 914, do CPC. (BRASIL, 2018). Os embargos à execução constituem uma ação autônoma de conhecimento, que se resolve por sentença de mérito. É lícito, ao executado embargante, autorizado pelo art. 917 do CPC (BRASIL, 2018), discutir nos embargos "[...] qualquer matéria que lhe seria lícito deduzir como defesa em processo de conhecimento". Como o prazo para a oposição dos embargos à execução inicia a contagem da juntada do mandado de citação aos autos da execução, a ampla defesa será sempre respeitada.

Talvez um elemento que cause estranheza seja a previsão que o legislador deu à defesa típica do executado no cumprimento da sentença. A forma será a impugnação ao cumprimento da sentença, que assume a natureza de incidente processado nos autos da execução. Em entendimento diverso, Araken de Assis define a natureza jurídica da impugnação ao cumprimento da sentença como uma "ação de oposição à execução", pois “insere-se uma pretensão (de oposição), cujo conteúdo variará da apresentação ao juiz de objeções (execução ilegal) ou exceções (execução injusta), ampliando o objeto do processo" (ASSIS, 2013, p. 1.353). O legislador, por motivos pouco compreensíveis, limitou o cabimento da impugnação ao cumprimento da sentença à execução e obrigação de pagar, definindo o dies a quo para a contagem do prazo de 15 dias como o primeiro dia após o término do prazo para o pagamento voluntário, independentemente de nova intimação, pelo que dispõe o art. 525 do CPC. (BRASIL, 2018).

Essa previsão legal não merece prosperar, pois o excesso de execução, motivo absolutamente plausível para a oposição de impugnação ao cumprimento da sentença, é argumento vinculado, além das obrigações de pagar quantia, às obrigações de fazer e entregar coisa, bem como à exceção por inadimplemento, conforme arts. $525, \mathrm{~V}$ e $917, \S 2^{\circ}$, do CPC 
(BRASIL, 2018), e o mesmo se aplica a todas as objeções e exceções apontadas por Araken de Assis. (ASSIS, 2013). Por este motivo, especialmente, a impugnação ao cumprimento da sentença deverá ser admitida em todas as hipóteses de execução do título executivo judicial.

Uma questão crucial diz respeito à matérias que o executado pode alegar em impugnação ao cumprimento da sentença. Diferentemente dos embargos à execução, as matérias da impugnação são limitadas pela lei. Embora exemplificativo, o rol do art. 525 do Código de Processo Civil (BRASIL, 2018), determina que o executado poderá alegar falta ou nulidade da citação se, na fase de conhecimento, o processo correu à revelia; ilegitimidade de parte; inexequibilidade do título ou inexigibilidade da obrigação; penhora incorreta ou avaliação errônea; excesso de execução ou cumulação indevida de execuções; incompetência absoluta ou relativa do juízo da execução; qualquer causa modificativa ou extintiva da obrigação, como pagamento, novação, compensação, transação ou prescrição, desde que supervenientes à sentença.

Veja-se que são matérias relativas à fase processual do cumprimento da sentença. E isso se justifica porque é impossível discutir, em impugnação ao cumprimento da sentença, questões que já foram atingidas pela preclusão ou pela coisa julgada na fase de conhecimento do processo. E, ao determinar a citação dos terceiros em desconsideração da personalidade jurídica, o magistrado já julgou o incidente sem a realização prévia de defesa dos citandos. A impugnação ao cumprimento da sentença não se presta para fazer o papel de recurso ou de ação rescisória. O momento processual oportuno para isso é o da fase de conhecimento. Questões como a inexequibilidade do título executivo afetam, tão somente, a fase executiva, sem alterar a decisão judicial que lhe dá suporte. 


\section{LIMITES LEGAIS PARA A APLICAÇÃO DO INCIDENTE NO CUMPRIMENTO DA SENTENÇA}

Conforme visto nos itens anteriores, a desconsideração da personalidade jurídica tem como foco a responsabilização pelo mau uso da atividade empresária e do contrato societário. A má-fé, o intuito de fraudar ou de prejudicar terceiros faz com que a aplicação do instituto tenha a finalidade de preservar a segurança jurídica e a legalidade, evitando o enriquecimento ilícito e, em especial, a ineficácia da tutela jurisdicional e o resultado útil do processo.

Ao realizar a desconsideração da personalidade jurídica, o juízo deve providenciar a citação de todos os envolvidos, consoante determinado pelo magistrado. Se a desconsideração for direta, os sócios deverão ser citados para integrar o polo passivo da demanda; se for inversa, a personalidade jurídica deve ser citada; se for entre grupos econômicos, todas as personalidades jurídicas e sócios envolvidos deverão ser citados. Como visto, é modalidade litisconsorcial de intervenção de terceiro.

O principal efeito da aplicação do instituto é, sem dúvida, a inoponibilidade dos limites do contrato societário ao juízo que processa a causa. Todos os litisconsortes passam a ser coobrigados ou corresponsáveis pelas obrigações a atos ilícitos controvertidos no processo. Um sócio pode responder com o seu patrimônio pessoal pela integralidade da dívida da personalidade jurídica, tendo, para si, o direito de regresso ante os demais litisconsortes. Trata-se do "redirecionamento da execução" (BUENO, 2017, p. 571), e esse ponto merece destaque.

O legislador trouxe previsão expressa acerca da legitimidade para figurar no cumprimento da sentença, tendo estabelecido expressamente, no $\S 5^{\circ}$, do art. 513, do CPC (BRASIL, 2018), que a ação executiva não poderá ser promovida "em 
face do fiador, do coobrigado ou do corresponsável que não tiver participado da fase de conhecimento". Faltou definir, porém, o que venha a significar "participado", se como parte ou qualquer outro sujeito do processo.

Não se pode limitar a legitimidade à atuação do sujeito como parte da fase de conhecimento pois, se assim for a interpretação do texto legal, o assistente simples, mesmo tendo atuado como substituto processual ou exercido direitos como o de recorrer, por exemplo, não teria legitimidade para ser executado quando codevedor. No mesmo sentido, o perito que não recebeu seus honorários aprovados por decisão judicial pode executar seu crédito como cumprimento de sentença nos mesmos autos em que atuou como órgão auxiliar do juízo, autorizado pelo art. 515, V do CPC (BRASIL, 2018), o que estaria impedido por lei caso a participação na fase de conhecimento fosse limitada à condição de parte. Essa interpretação merece a amplitude da participação genérica.

Com base nesse entendimento, surge a problemática aqui apresentada: quais são os limites legais para a desconsideração da personalidade jurídica no cumprimento da sentença?

Usando a modalidade direta como exemplo, o sócio que não participou do processo em sua fase de conhecimento como representante da pessoa jurídica, como preposto, ou mesmo como depoente, não pode figurar no polo passivo do cumprimento da sentença. Isso porque nunca tivera a oportunidade de exercer a defesa dos seus direitos na fase de conhecimento, e não pode ser atingido pela preclusão e pela coisa julgada. O Código de Processo Civil traz vedação expressa a qualquer interpretação diversa, pois prevê, em seu art. 506, que "[...] a sentença faz coisa julgada às partes entre as quais é dada, não prejudicando terceiros." (BRASIL, 2018).

A solução para a hipótese de desconsideração direta da per- 
sonalidade jurídica, na fase de cumprimento da sentença, é a decisão modular. $\mathrm{O}$ magistrado, mediante análise minuciosa dos autos, deverá dar por procedente o pedido de desconsideração da personalidade jurídica delimitando quais serão os sócios que possuem legitimidade para figurar na fase executiva, com base em sua participação na fase de conhecimento - é a modulação subjetiva. Os que, de nenhum forma, participaram da fase de conhecimento, não poderão ser citados, e aos litisconsortes caberá a ação de regresso contra aqueles. Não há novidade nessa afirmação, já que o Superior Tribunal de Justiça, em situação semelhante,editou a súmula n. 435, segundo a qual, "[...] presume-se dissolvida irregularmente a empresa que deixar de funcionar no seu domicílio fiscal, sem comunicação aos órgãos competentes, legitimando o redirecionamento da execução fiscal para o sócio-gerente.” (STJ, 2018).

Já a desconsideração inversa da personalidade jurídica e a desconsideração entre grupos econômicos encontra o mesmo óbice, que tem efeitos ainda mais restritivos. Muito provavelmente a pessoa do sócio terá atuado sozinha na fase de conhecimento, sem qualquer participação da sociedade ou dos demais sócios, defendendo interesse pessoal. A pretensão que gerou a ação de conhecimento será pessoal, e a personalidade jurídica da qual é sócio não terá absolutamente nenhuma oportunidade de defesa de direitos. Fazer a desconsideração da personalidade jurídica para atingir o patrimônio da sociedade é violar expressamente todos os dispositivos legais acima apresentados, é violação ao devido processo legal. E o mesmo se aplicará à sociedades empresariais de mesmo grupo econômico.

A ilegitimidade para figurar na fase de cumprimento da sentença impede a efetivação da desconsideração da personalidade jurídica inversa e a de grupos econômicos. Autoriza, em parte, a desconsideração direta, desde que a decisão seja modulada em relação aos sujeitos. Isso não impedirá, por óbvio, 
posterior ação em que as partes atingidas venham a buscar o seu regresso. Essas conclusões não são boas, sob o aspecto social e da segurança jurídica, mas tornam necessárias em razão do sistema processual, e resultam na inevitável crítica ao legislador, que perdeu uma excelente oportunidade de criar um procedimento bem definido e adequado à boa técnica processual.

\section{CONCLUSÃO}

O instituto da desconsideração da personalidade jurídica, como intervenção de terceiro, é incidente que deve ser resolvido por decisão própria. Nessa decisão, obrigatoriamente, o magistrado deverá reconhecer a existência dos requisitos legais que a autorizam. Faltou, porém, a definição desse procedimento pelo legislador.

Isso porque o incidente é instaurado ante aqueles que efetivamente participam do processo até aquele momento. Se for desconsideração direta da personalidade jurídica, somente a pessoa jurídica, representada por seu administrador, irá participar do incidente e exercer o seu direito à ampla defesa. Se for inversa, somente o sócio participará. E, se for entre grupos econômicos, somente a pessoa jurídica demandada.

Serão dois os momentos de defesa de direitos a serem respeitados pelo magistrado no processo: a fase de conhecimento, que dá ensejo à sentença; e o incidente da desconsideração da personalidade jurídica. O legislador limitou o exercício do direito de defesa do terceiro ao peticionamento, nos autos, em 15 dias. Esse peticionamento, por óbvio, se referirá ao acerto ou ao erro do magistrado em julgar procedente o instituto da desconsideração. E esse, talvez, seja o maior dos problemas da instauração do instituto na fase de cumprimento da sentença.

Se o terceiro for trazido ao processo por força da desconsideração na fase de conhecimento, poderá fazer uso de todos os 
meios de defesa em direito admitidos, cabendo ao magistrado lhe conceder a faculdade de agir sob pena de violação ao postulado constitucional da ampla defesa. A sentença o atingirá, mas somente após a análise, pelo magistrado, de todos os elementos que, em tese, possam resultar na sua convicção. Dentre eles, aqueles apresentados pelo terceiro que passou a integrar o polo da demanda juntamente com a pessoa jurídica que tivera a sua personalidade desconsiderada.

Porém, se a desconsideração da personalidade jurídica ocorrer após o trânsito em julgado da sentença, o terceiro nada poderá fazer em relação a ela além da propositura de uma ação rescisória, cujos requisitos não estão relacionados estritamente com a ampla defesa. Também não poderá alegar que a sentença é nula sob tal argumento. O único argumento que lhe restará será, eventualmente, a ilegitimidade para figurar nessa fase do processo.

É salutar que o magistrado, ao julgar procedente o incidente de desconsideração da personalidade jurídica, o faça através de decisão modular. E duas serão as possibilidades, nesse sentido: a modulação objetiva e a modulação subjetiva. Na modulação objetiva, definirá exatamente quais serão as obrigações e as responsabilidades que tornarão inoponíveis as previsões do contrato social. No modulação subjetiva, definirá quais serão, exatamente, os terceiros que terão legitimidade para integrar o polo da demanda em litisconsórcio com a pessoa jurídica.

Se a desconsideração for julgada procedente na fase de cumprimento da sentença, caberá ao magistrado, na decisão, definir quais os sócios que efetivamente participaram do processo em sua fase de conhecimento, sob pena violação aos postulados constitucionais da ampla defesa e, por conseguinte, do devido processo legal. Quem não participou será, invariavelmente, ilegítimo. 


\section{REFERÊNCIAS}

ASSIS, Araken de. Manual da execução. 15. ed. São Paulo: RT, 2013.

BRASIL. Código civil, Lei n. 10.406, de 10 de janeiro de 2002. Disponível em: $<$ http:// www.planalto.gov.br/ccivil_03/Leis/2002/110406.htm>. Acesso em: 5 jun. 2018.

BRASIL. Código de defesa do consumidor, Lei n. 8.078, de 11 de setembro de 1990. Disponível em: <http://www.planalto.gov.br/ccivil_03/Leis/18078.htm>. Acesso em: 5 jun. 2018.

BRASIL. Código de processo civil, Lei n. 13.105, de 16 de março de 2015. Disponível em: <http://www.planalto.gov.br/ccivil_03/_ato2015-2018/2015/lei/113105.htm>. Acesso em: 5 jun. 2018.

BRASIL. Superior Tribunal de Justiça. Informativo n.0524, de 28.08.2013. Disponível em: $<$ https://ww2.stj.jus.br/jurisprudencia/externo/informativo/>. Acesso em: 5 jun. 2018.

BRASIL. Superior Tribunal de Justiça. Informativo n.0533, de 10.02.2014. Disponível em: $<$ https://ww2.stj.jus.br/jurisprudencia/externo/informativo/>. Acesso em: 5 jun. 2018.

BRASIL. Superior Tribunal de Justiça. Informativo n.0544, de 27.08.2014. Disponível em: $<$ https://ww2.stj.jus.br/jurisprudencia/externo/informativo/>. Acesso em: 5 jun. 2018.

BRASIL. Superior Tribunal de Justiça. Informativo n.0554, de 25.02.2015. Disponível em: $<$ https://ww2.stj.jus.br/jurisprudencia/externo/informativo/>. Acesso em: 5 jun. 2018.

BRASIL. Superior Tribunal de Justiça. Informativo n.0602, de 24.05.2017. Disponível em: $<$ https://ww2.stj.jus.br/jurisprudencia/externo/informativo/>. Acesso em: 5 jun. 2018.

BUENO, Cássio Scarpinella (Coord.). Comentários ao código de processo civil, (arts. $1^{\circ}$ a 317). São Paulo: Saraiva, 2017. 1 v.

FOSS. Nicolai J. Opções reais e a teoria da empresa. Tradução Luiz Gustavo Lovato. Disponível em: <http://www.paginasdedireito.com.br/index.php/artigos/68-artigos-fev-2008/6016-opcoes-reais-e-a-teoria-da-empresa>. Acesso em: 18 maio 2018.

FRANZOI, Juliana Borinelli. O princípio do contraditório no cumprimento da sentença: defesas do executado. In: LUCON, Paulo Henrique dos Santos; OLIVEIRA, Pedro Miranda de (Coord.). Panorama atual do novo CPC. Florianópolis: Empório do Direito, 2016.

GOMES, Orlando. Introdução ao direito civil. 12. ed. Rio de Janeiro: Forense, 1996.

LOVATO, Luiz Gustavo. Curso de processo civil: execução. Rio de Janeiro: Lumen Juris, 2017. $5 \mathrm{v}$.

LUCON, Paulo Henrique dos Santos; OLIVEIRA, Pedro Miranda de (Coord.). Panorama atual do novo CPC. Florianópolis: Empório do Direito, 2016.

MEDINA, José Miguel Garcia. Novo código de processo civil comentado. 4. ed. São Paulo: RT, 2016.

NEGRÃO, Ricardo. Manual de direito comercial de empresa. 5. ed. São Paulo: Saraiva, 2007. 